\title{
Public Accountability through Soft Steering
}

UDK: 005.35

Michiel S. de Vries

Radboud University Nijmegen/University of Aruba

m.devries@fm.ru.nl

Iwona Sobis

Gothenburg University

iwona.sobis@gu.se

\section{ABSTRACT}

This article argues that present-day procedures on public accountability miss the essence of being accountable. We suggest that alternatives are available in social psychology theory and network theory, which point to the decisive role of peers or experienced organization members. In this view, it is not leadership but middle management that is crucial in the socialization of newcomers in an organization to internalize values and to create a situation in which employers and employees develop mutual expectations about what is expected from one another and create multiplex networks in order to maintain such values.

Keywords: Accountability, socialization, network theory, reduction of administrative costs, social psychology

JEL: D23

\section{Introduction}

Public accountability is becoming increasingly important. In older times, accountability only came up when grave situations, i.e. disasters, occurred. Accountability involved control and answerability, often related to sanctions that had personal consequences aimed at righting wrongs. Recently, the practice changed into what some call "new" or "managerial accountability". This new kind of accountability emphasizes informationexchange, behavior and performance explanation, trust, and horizontal relations between the account-holder and the accountee (cf. De Vries, De Vries, M. S. \& Sobis, I. (2012). Public Accountability through Soft Steering. 
2007). It is based on the idea that everyone is essentially accountable to everyone and all must be able to justify their actions.

This new form of accountability evolved in the last decades of the 20th century and the first decade of the new millennium. It addresses the responsibility and trustworthiness of officials and agencies, ways to minimize abuse of power and authority, and strategies and sanctions to ensure that those in authority comply with acceptable standards (Ayeni, 2004). A major idea behind what is now called "public accountability" is that public bodies are accountable to the public, i.e. they should not waste the taxpayers' money, they should be economical and efficient in achieving goals and they should be effective in the long run. In spite of these worthy goals, there are a number of negative side effects of this type of accountability. We mention five:

The first problem relates to an increase in administrative costs. Since accountability has become more or less routine within the public sector as opposed to being event-related or trigger-induced, the number of reports under the heading of accountability has increased rapidly. Within the framework of public accountability, governments are often required to include a mandatory evaluation in their new laws and regulations. All new policy should be monitored and evaluated within 2-3 years of implementation. Furthermore, central government often demands periodic information from its governmental agencies and private business, regarding safety, environment, labor, et cetera (Power, 1997; Bowerman et al., 2000). Although this is fairly standard practice, the costs involved are substantial. As Olson, et al., write: »Information is not a free good. Collecting data, structuring data and reporting information consumes time and costs money« (Olson et al., 2001, p. 511 ; Boyne, 1998; Kirkpatrick, 1999).

The second problem is that the information gleaned from the accountability practices is rarely used. The administrative costs would be acceptable if public decisions were based on the information that the accountability measures provided. In reality, however, the reports are rarely discussed or debated and they seldom serve as the source for new public policies.

This is related to the third problem, namely the positive bias in such reports with regard to what has been achieved and what the agency wants to achieve. This bias should cause us to question whether such accounts 
are really as informative as they could be. As Olson, et al., tell us, "The rise of 'self-audits' (under traditional auditing concepts of independence, a blatant contradiction in terms) is a classic illustration of the increased importance and trust placed in processes of formal accountability" (Olson, et al., 2001, p. 510). The lack of control and consequences in presentday accountability processes provides ample opportunity for the agency conducting the self-audit to present what is in its own interest regardless of whether it is an accurate or complete picture of what really is going on (Olson et al., 2001).

The fourth problem of the modern approach to accountability is that when something goes wrong, a disaster happens or fraud is detected, it is often unclear who is responsible and that one has to refrain from sanctions, because it is unclear who is to be accused. If every public agency is accountable to every other public agency, it becomes difficult to determine which agency should have taken action to prevent the disaster. The complexities of collaborative government, the implementation of privatization, and the creation of semi-independent agencies, quangos and the like, have made it difficult to point directly at an individual actor as the responsible party. Instead, everyone points to everyone else others who were similarly informed and gave their consent. The recent British Petroleum oil spill in the Gulf of Mexico is a good example of a situation where everybody was involved, yet no one could be found guilty.

The fifth problem - also seen in the oil spill - is that public accountability often comes at the expense of individual responsibility. If something is simply accounted for, i.e. shown to be within the laws and regulations, it is viewed as allowable - regardless of one's own responsibility, values and norms. This is detrimental for public service motivation, and especially norm-based and affection-based motives that fuel the desire of public employees to serve the public interest and help others. Instead, the organization is left with individuals who are mainly rationally motivated and grounded in individual utility maximization, (Perry, 1996; Brewer, 2000).

This last problem is the main issue addressed in this paper. How can we incorporate and maintain norm-based and affective motives in public organizations? Our main response is that we need to exchange our focus on leadership with increased focus on the role of colleagues, especially the more experienced organizational members. We believe it is important 


\section{Public Accountability through Soft Steering}

that first, the more experienced cadre of individuals handle the socialization of newcomers, and second, that they create dense networks that build trust among coworkers by creating interrelationships, information-exchanges, connectivity and especially multiplexity.

Scholars frequently point to the crucial role of leadership and the importance of proper hierarchical coordination in order to change the minds of the people working in the organization (Sobis, De Vries \& van den Berg, 2012). Although exemplary behavior at the top of the organization might have some impact on the behavior of personnel on the work floor, we argue that peers' behavior is much more important. In our opinion, the importance of leadership is overrated. The exemplary nature of leadership often fails because of the distance between leadership and people on the work floor. Most of what leaders do is invisible to employees and/or susceptible to misinterpretation; direct relations between leaders at the top of the organization and individual workers are often minimal or even absent. It seems to make more sense to focus on the influence of peers, i.e. middle management, or experienced organization members on individual employees because the frequency and intensity of their relations is usually greater and therefore might be more influential.

It is for this reason that the authors have sought out theories in different scholarly disciplines related to Public Administration that result in practical recommendations about how experienced organization members can motivate their colleagues to do what they are expected to do - which is the essence of public accountability - without hierarchical steering or continuous monitoring and evaluation.

The answer suggested by an increasing number of scholars in Human Resource Management is that this is best accomplished by propagating commitment and compassion - emphasizing affective motivation, two aspects of work that are underrated in management practices that emphasize routines and values skills and outputs.

In the next section, we discuss the importance of addressing these basic aspects of work. Highlighting their importance is a first step in creating a responsible organization. An important question at this point is, "How do we go about changing an organization into one that values commitment and compassion? « Answers to this question are provided by socialpsychological theories and network theories. Section 3 gives a brief 
account of these two theories and their implications for our issue. We want to emphasize that although these theories provide answers, we do not yet believe they are the final answers. The two theories provide an idea or starting point for the research question underlying this article, namely, how to make public accountability work in such a way that it enhances responsibility among the stakeholders. In the conclusion, we discuss other theories that might be interesting in this regard.

\section{The neglect of emotion}

The most important deficiency in present-day performance measurement is the obvious neglect of those aspects of work that cannot be easily measured but often matter most, i.e. the inability of performance measures to measure what is relevant. In management and organization theory, it is becoming increasingly acknowledged that performance measurement has a bias towards measuring skills and measurable output indicated by knowledge, productivity, quality, initiative, allocation of time, planning, and development. It marginalizes the emotional aspects involved in public service such as courtesy, credibility, motivation, tact, patience, reassurance, empathy, understanding, persuasion, consultation, caring, commitment to the welfare of the client and the importance of the program, coaching, guiding and comforting clients (Guy, Newman \& Mastracci, 2008). As critics argue, the motivation in delivering services to the public goes beyond rational aspects and includes norm-based and affective motives (Knoke \& Christine Wright-Isak, 1982). The dominant way of steering by hierarchy and collecting large amounts of information in order to increase rationality, only optimizes skills and maximizes efficiency.

The trend towards rationalizing the workplace and excluding the emotional aspects is in itself nothing new; it was visible as early as the 1920s when the efficient functioning of government was compared to a machine. Van Riper argued that from the start, public administration has moved in an increasingly instrumental and managerial direction, valuing the application of scientific methodology to the resolution of public issues and building an identity of neutral expertise (Guy, Newman \& Mastracci, p. 44). Frost et al. (2005) also point to the fact that the desire to see organizations as purely rational and calculated systems has a long history in organizational studies (Frost et al., 2005, p. 2) The emphasis on scientific management and what has become known as Taylorism 
provided a strong foundation for stripping away a focus on humanity in the workplace, a tendency that has continued with organizational scholars who demonstrate a greater concern for society's economic ends rather than its social ones (Frost et al., 2005, p. 3).

In recent decades, this has become more explicit, because of the dominance of the public choice paradigm and the emerging dominance of New Public Management [NPM] (Pollitt \& Bouckaert, 2004).

The Public Choice paradigm is based on a model of human behavior in which people are assumed to be motivated primarily by self interest. According to this view, because self interest is at the root of human behavior, incentives, organizations, and institutions have been and must be designed to recognize and take advantage of such motivations (Perry \& Wise, p. 367). NPM mainly promoted efficiency and furthered the dominance of technical skills while neglecting the intrinsic value of commitment to programs by officials (Downs, 1967), out of the conviction about its social importance (Perry \& Wise), and what some called the patriotism of benevolence (Frederickson \& Hart, 1985).

In the last couple of years, a movement has emerged that argues that in everyday delivery of public services, emotions are found everywhere (Guy, Newman \& Mastracci, 2008), and they should not be marginalized. In their book on "Emotional Labor", Guy and Newman provide ample illustrations from prison wards, correctional officers, and criminal investigators to 911 -call operators, and they point out the importance of being able to deal with, show and manage emotions in everyday work. Nowadays, this research field in which commitment, passion and compassion are addressed is booming. The 2010 slogan of the Academy of Management conference in Montreal was "Dare to Care " and on the internet, numerous and ever increasing number of websites can be found on this topic. The research into this topic is rapidly increasing, but it is especially increasing in business administration and much less in Public Administration. This is a shame because the topic is as important in public service delivery and public accountability.

That emotions are also important in the public sector has been argued in research into the work of western advisors in Central and Eastern Europe during its transition (Sobis \& de Vries, 2009). There, we argued that the classic values of professionalism, i.e. commitment, empathy, information accuracy, caring, building expertise, using interventions that best suit 
the situation at hand (responsibility), and making recommendations only when they are based on sound problem diagnosis, are increasingly viewed as old-fashioned values that need to be replaced by more rational values. These rational values include the following: advice is detached and objective, advice is aimed at maintaining appearances and promoting financial gains for the advisor, the advisor's credibility is based on his/her formal education, and his/her interventions are based on standard setting and prefixed goals. We demonstrated that advice based on this new, more rational conception of professionalism mostly falls flat (Sobis \& de Vries, 2009).

In other research, de Vries, (2010) argued that in the case of Dutch municipalities, no matter how rational the organizations were, the effectiveness of their policies suffered as a result of interpersonal conflicts - which are full of emotions. It was also argued that when continuous change and reorganizations of local administrations took place without considering the emotional aspects of work, there was an increase of interpersonal conflicts. Up to $45 \%$ of Dutch local elites mentioned this as the main problem their municipality faces, i.e. the existence of interpersonal conflicts within city hall. Those involved perceived such conflicts as the municipality's main impediment to developing effective policies and service delivery.

The outcomes of that research and many other investigations suggest that the neglect of emotions is detrimental to organizational development and effective service delivery. As Kahn wrote in 1998, compassion is an essential part of care-giving that is part of, not separate from, work interactions (Kahn, 1998, p. 43) and as Guy, Newman and Mastracci argue, it is a critical component of fully one-third of all occupations and fundamental to public service and public management practice (Guy, 2008, p. 172).

Frost et al., (Frost, 2005) identify »compassion as comprised of three interrelated elements: noticing another's suffering, feeling empathy for the other's pain, and responding to the suffering in some way ... Noticing involves a process of becoming aware of another's emotional state, and typically requires being open and attentive to emotional cues and to what is happening in one's context ... Compassion resembles empathy (Davis, 1983), but goes beyond this to involve a response to suffering. 
Responding indicates action in which one attempts to alleviate or overcome the other's condition in some way."

The above suggests that responsible organizations need compassionate, caring people, but it does not tell us how to build such an organization. The question of how to develop organizations that value and incorporate attention for emotions is still unanswered.

Some argue that compassion should be propagated by leaders since their actions can offer important symbolic endorsements of what is an appropriate or inappropriate feeling (Pfeffer, 1981). Others argue that it involves coordinating the processes in which people arrange interdependent actions in ways that will enable them to accomplish their goals (Weick, 1995). Without structures and systems in place to coordinate member responses, joint efforts to offer compassion may fail as good intentions dissipate for lack of means to turn efforts into tangible help (Frost, 2005). Still others argue that creating a compassionate organization involves more than just a new type of reorganization. There is a need to view salient organizational interdependencies as being inherent in an organization, to see the development of compassion as a dynamic process and to recognize the influence of feedback loops on the nature and direction of compassionate acts, which also need to be historically embedded.

However, this is still rather vague and procedural, and it neglects the fact that there is typically some distance between leadership and employees on the work floor; that coordination is often only another word for identifying the problem instead of a substantive solution; and that creating historical embeddedness is a goal instead of an instrument to build a responsible organization. The suggestions do not tell us what must be done in practice to build organizations in which people do what they are expected to do because they are committed to their work, care about the welfare of the client and are committed to the importance of the program, coaching, guiding and comforting clients.

Below we argue that two theories could be relevant for answering this question; social psychology, in which socialization is important, and network theory, in which the density or multiplexity of relations is believed to be crucial in shaping working conditions in this direction. Although our search for a more comprehensive answer is still ongoing, these two theories provide a good start for our investigation. 


\section{Social psychology theory}

One of the major tasks of social psychology is explaining how people's values are influenced by other people in their social world (Kaplan, 2001, p. 2772). One of its theories argues the following: Values and norms are relatively stable, and individuals are only susceptible to changes in their values and norms at certain moments in life, for instance, when they enter a new situation. At those moments, people can be socialized; they can successfully enter a learning process in which they internalize values, norms, attitudes, social roles and statuses of the groups or organization to which they begin to belong (Mead, 1934/1976; Goslin, 1999; Gecas, 2001). Especially important is that such socialization deals with the cognitive dissonance that is bound to occur. The values and norms that the individual already holds might not be a perfect with the values and norms central to the organization, and this cognitive dissonance could result either in indifference, apathy or stress. Simply giving a financial reward for conducting behavior that the employee actually deploys only increases the cognitive dissonance and thus the indifference or stress.

Theories in social psychology suggest tools to avoid this and to alter the values of employees by changing their current cognitions. According to social psychology theory, socialization - especially by experienced organization members/colleagues - is believed to be advantageous. A well conducted peer socialization process provides new employees with criteria to assure them that when they face a certain situation that requires changing, adding or reevaluating their cognitions, they do so in the direction the mission of the task requires. Such socialization results in clarity and congruence between the mutual expectations of employers and employees and can even result in what is called in social psychology a psychological contract, that is clarity about whe actions employees believe are expected of them and what response they can expect in return from the employer« (Wellin, 2007, p. 27).

\subsection{About values and norms}

Margaret Mooney Marini (Marini, 2001) presented a consistent theory that distinguishes values and norms - two useful concepts that explain human behavior and help us understand the world in which we live. Values involve people's "cognitive beliefs of approval or disapproval« (op. cit. p. 2828). A value is seen as »a belief about the desirability of a mode, means, or end of action« (op. cit. p. 2828) i.e., a value informs what is 
perceived as a good or a bad behavior. A value can be seen as a particular type of motive that involves "a belief about desirability of an action that derives from evaluation of that action's expected consequences in a situation « (op. cit. p. 2829). Regarding the concept of "norm", Marini explains that in many respects, a norm plays a role for individuals' that is similar to a value. It is also an evaluative belief based on morality, aesthetics, and achievements. However, a value puts stress on the desirability of behavior, while »a norm is a belief about the acceptability of behavior« (op. cit. p. 2829).

One of the major findings in Social Psychology is that values and attitudes are rather stable. A political regime can be changed from communism to capitalism, but this does not automatically imply that the individuals' values alter the change of the regime (Rokeach, 1973). This implies that: (1) it is difficult to change values, and (2) if such a change of values is accomplished, it will probably be a lasting change. As social psychologists argue, there are only a few of periods of time that individuals are more open for value-change: in their early youth, when they enter high school, when they enter college, and when they begin their first job. It is at these moments that values, attitudes, and norms can be created and changed, through what social psychologists call a process of socialization i.e., through exposure to the opinions and actions of other members of society or the organization.

\subsection{Socialization}

Socialization can be seen as a learning process in which an individual internalizes values, norms, attitudes, social roles and statuses of the groups to which he/she started to belong. Socialization can also be seen as the formation of self. George Herbert Mead (Mead, 1934) identified the self as a reflexive phenomenon that develops through symbolic interaction by the use of language with significant others known also as "the generalized others".

Primary socialization occurs mostly in the family. Successively, we observe secondary socializing agents appearing like play groups and work groups. They continue the process of socialization by rewards and punishments to induce proper norms for behaviors. Life is like wandering through different family constellations, schools, sport-clubs, recreational settings, political parties, religious organizations, voluntary associations, workplaces, trade unions, professional organizations, even different states or different 
marriage relations etc. All these institutions or organizations are socialization-agents. Each time people come under new influences, their world changes and so might their values, norms and attitudes change (see e.g., Rokeach, 1973; Jennings, 1968; Goldsen, 1960). Therefore, socialization that occurs at the workplace during the first year when a new employee enters the organization is so important. Such socialization can accomplish the internalization of specific values, norms and attitudes to result in the new employee's effectiveness, but also to secure their coherent and exemplary behavior. Such socialization should be conducted by middle management also known as "experienced organizational members". It plays a decisive role, because it enables new employees to become socialized in the "right culture", from the beginning (Tannenbaum, et al., 1992). They should receive response from experienced organizational members about their performance.

As to the format of such socialization, the literature suggests that the sustainability of the acquired knowledge, skills and incorporated values, norms and attitudes varies due to tactics used when socializing (e.g., Van Maanen \& Schein, 1979). Van Maanen and Schein distinguished between collective versus individual socialization, formal versus informal socialization, sequential versus random socialization, fixed versus variable socialization, serial versus disjunctive socialization, and investiture versus divestiture. Cable (1994) points to the importance of the sequential, formal, serial, and investiture nature of socialization understood as structured career progression and institutionalized training programs, as well as the provision of role models and support from experienced organizational members.

\subsection{The contents of socialization}

Social psychology points to the requirement that the contents of socialization are focused on dealing with cognitive imbalance and cognitive dissonance. Heider (Heider, 1946, 1958), the father of theory on cognitive balance, assumes that individuals strive for stable systems. Personal stability is achieved when the individuals I like, like the same people and things that I like. It emphasizes belonging to a group. It is relevant for explaining friendship, conformity, and people's reactions to criticism. Heider predicted that actors try to alter a situation if they feel a cognitive imbalance. They simply strive for balance, and this balance is much more important for them than mere contentment. 
Osgood and Tannenbaum (Osgood, 1957) argued something similar in their incongruity theory. People tend to avoid a cognitive imbalance by decreasing the importance of their original values. If a positive and negative object are linked, the tendency is toward neutrality i.e., indifference. Looking upon it from a public administrative perspective, imbalanced situations can explain increased bureaucratization, an emphasis on procedures, indifference and detachment.

Festinger's theory on cognitive dissonance from 1957 points out that dissonance occurs if two elements of knowledge are in such a relation that when only considering these elements the obverse of one element would follow from the other. Every person will try to reduce dissonance and to achieve consonance. It implies that people seek evidence to confirm their actions to make their actions congruent with their attitudes. People change preferences under the strain of dissonance. This theory poses a quite different light on incentives, the role of utility and its influence on behavior. According to this theory, reducing cognitive dissonance is much more important in explaining choices than maximizing utility. In the famous Festinger-Carlsmith experiment (Festinger, 1959), people disliking a task e.g., making a false testimony, were offered an incentive to do so. The experiments showed that the higher the incentive the less enjoyable the task was perceived. Thus, the reward for doing something one does not like to do cannot compensate for the "bad" behavior. Festinger's theory explains the outcomes by the distance between the positively perceived reward and the negatively perceived task that makes people feel uncomfortable. The experiment was repeated many times by different social psychologists and is known as the reverse incentive experiment.

According to Mead's theory about self-perception (1934), one's own behavior is seen as the product of social interaction. Every organization should therefore accomplish some kind of interaction among its employees to teach them how to respond to external and internal stimuli, how to evaluate themselves and handle the tasks in the expected way. The questions we should ask are; to what or to whom do employees refer to when judging their performance and how to induce them to use a proper reference-frame. Does it accord to plan? Does one follow procedures? Does one fill in all of the questions in the evaluation report? Does one accomplish the prescribed goals? 
This situation is similar to the findings coming from an alternative theory created by Bem (1972). In this theory about self-perception, it is supposed that people infer their attitudes from their behavior in the same way outsiders do. It asserts that we can only have that knowledge of our own behavior and its causation that another person can have, and that we therefore develop our attitudes by observing our own behavior and conclude what attitudes must have caused them. Hence, if we are forced to act in a particular way, our attitudes towards the work will change accordingly. Central is the question "what must my - this man's - attitudes be if I am - he is - willing to behave in this fashion in this situation « (Bem, 1972, p. 28). If I am behaving this way, my attitudes must be like this and hence, these are thus, my attitudes.

\subsection{The result of socialization}

The result of such socialization is a psychological contract; it is unlike the normal contract in which the duties, the pay, and all kind of legal arrangements are established. It "relates to our mind and therefore is intangible« (Wellin, 2007, p. 17). Argyris (1960) first used the term of psychological contract and defined it as the implicit understanding between a group of employees and their supervisor. He sketched the "psychological work contract" in exactly the way that we search for i.e., "the employee will maintain high production « and reduce oversight and control, while wthe foreman guarantees and respects the norms of the employee informal culture by allowing him/her to make a certain job, provide him/her with adequate wage and secure his/her job.

Schein (Schein, 1965) later defined the psychological contract as the unwritten expectations operating at all times between every member of an organization and the various managers and others in that organization. While each employee has expectations about his/her salary or pay rate, working hours, benefits and privileges that go with a job, the organization also has its own expectations that e.g., the employees will enhance the image of the organization, will be loyal, will keep organizational secrets, and will do their best.

More recently, Denise Rousseau (Rousseau, 1994, 1995), redefined the psychological contract as something that essentially exists in each individual's head, as the sindividual beliefs, shaped by the organization, regarding terms of an exchange agreement between individuals and their organization« (Rousseau, 1995, p. 9). Wellin perceives the psychological 
contract as wthe actions employees believe are expected of them and what response they expect in return from the employer (Wellin, 2007, p. 27). As such, the psychological contract cannot be laid down on paper as some companies think or something to be agreed upon during the last phases of recruitment. In its original meaning, it is something that emerges from a socialization period.

\subsection{Lessons from socialization theory}

Social Psychology argues that in order to build an organization in which values and norms are internalized by its employees, the following are necessary:

1. Socialize newcomers during the first year they enter the organization to shape their attitudes. Clear guidance that transfers the right values and professional attitude is indispensable;

2. Expose them to situations in which cognitive imbalance, incongruity or dissonance is bound to occur and train them to adjust, add or reweigh their cognitions in accordance to the values of trusteeprofessionalism;

3. Recognize that the decisive role of experienced middle management is much more crucial than the role of leadership. Middle management will mainly guide new employee/new professionals and transfer the values and attitudes to the newcomers that is of great importance for the organization;

4. Strive for an implicit mutual understanding of expectations - a psychological contract - which is not just a transactional contract about pay for performance, or an individualized employment contract, but the result of an extensive process of socialization that involves learning and adaptation process of cognitions by which mutual and apparently justified trust is created and oversight can be diminished accordingly.

\section{Network theory}

Notwithstanding the strength of the argument of socialization theory, one can dispute its claim that socialization has lasting value and does not require follow-up in order to retain the values and norms of the employees. It might well be that although values are relatively stable, they could fade after a couple of years. What can be done to prevent this? 
Network theory, originally developed to understand inter-organizational relations, provides an answer to this.

The first systematic studies about networks, networking and building coalitions in organization are from the late 1950s and 1960s (Evan, 1966). This classical research described interactions among individuals across organization that aim to create networks for getting things done and exchanging information. These interactions often go beyond the formal structure of organization, and it is assumed that much more is accomplished than would be the case with only formal channels of organization. Creating a network is seen as a somewhat simple task; identify people who could be helpful in the process of trying to achieve expected objectives, establish their reliability, and then actively seek their cooperation. Literature on this subject shows that a similar function i.e., "getting things done in organization « is involved in creating alliances i.e., "getting agreement on a course of action with other people and joining forces to get things done« (Armstrong, 2006, p. 301).

According to Evan (Evan, 1966), social science research up to that point was primarily concerned with networks as inter-organizational phenomena, and theory and methodology impeded research on interorganizational relations. To solve this problem, Evan suggested two methodological tools that could prove useful in the development of empirical research on inter-organizational relations i.e., graph theory and input-output analysis. The first one was developed as research dealing with network visualization, and the second one is known as transaction cost economics [TCE].

During 1980s and 1990s, scholars and practitioners described the growing interest in networks and multi-organizational relations that are usually created to solve complex problems - mainly occurring in the private sector but also in the public one. A network was defined as ithe group of more or less independent organizations that have a relative stable and long-term cooperation« (Grandori \& Soda, 1995). More recently, theorizing on inter-organizational networks has started to evolve. Recent theories are based on assumptions similar to individual networks:

1. Actors (organizations) are influenced by the social contexts within which they are embedded,

2. organizational fields serve as significant environments for their members, 
3. the inter-organizational structures, and not the characteristics of a field, determine performance, and

4. the relational structures of the field-net per se, as opposed to the position of the actors in the field, determine the performance of the actors involved and the performance of the network as a whole (Kenis \& Knoke, 2002, p. 290).

The solutions that network theory suggests address, among other things, the following problems: the prevention of opportunistic behavior and moral hazard, the reduction of transaction costs, the improvement of the performance of organizations within the network, and more recently, the performance of the network as a whole (Provan \& Kenis, 2007).

These theories attempt to explain the nature and consequences of specific types of relationships among actors, be it organizations or members within an organization and suggest solutions as alternatives for hierarchy, especially when the latter is failing. A major problem is the difficulty of recruiting critical stakeholders, maintaining active member involvement, promoting a collaborative work culture, and achieving collaborative outcomes (Foster Fishman, et al., 2001, p. 901).

Such alternatives can be found in alliances, partnerships and networks. However, many other connotations also exist (Cropper, et al. 2008, pg. 4-5; Van de Ven, 1976; Galaskiewicz, 1985; Oliver, 1990; Barringer \& Harrison, 2000; Cropper et al., 2008). These theories assume that it is not the field of work or the position of actors in a network that explain its performance; instead, performance is determined by the structure of the network as a whole in terms of its density, its embeddedness, and its interaction patterns. Provan, Fish \& Sydow conclude that "Only by examining the whole network can we understand such issues as how networks evolve, how they are governed, and ultimately, how collective outcomes might be generated. This last point is especially relevant to policy planners and those having a perspective that goes beyond the performance of individual organizations« (Provan, 2007, p. 3).

According to this line of thinking, the varying performance of organizations inside a network or individuals inside an organization is based on the centrality, connectivity, density, and the multiplexity of their relations in the network as a whole. 
Embeddedness is created by either dictating (establishing hierarchy) or communicating (establishing social bonds) or both. This relation is generated by intermediary factors such as trust, incentive structures, resource dependence, network density, centrality, clustering, and multiplexity in the relations.

\subsection{Assumptions and outcomes of research in networks}

The main assumptions and factors to consider when analyzing networks can be summarized in term of a network's:

1. Context; the assumption is that actors are influenced by the social contexts in which they are embedded. The contexts are characterized by varying complexity, uncertainty, ambiguity, dynamics, and institutionalization.

2. Developmental phase; the assumption is that the way that organizational fields serve as significant environments for their members is underlined by awareness and partner selection, and dependent on the degree to which the network has evolved, i.e., whether it is in the exploration, expansion, or commitment phase.

3. Types of governance; the assumption is that the performance of actors depends less on the characteristics of the field of study than on the contextual structures, such as management, centrality, and resource dependency (Provan \& Kenis, 2007).

4. Structural features; the assumption is - the performance of the network as a whole is determined by the relational structures of the field-net per se, not by the positions of actors in a network (Kenis \& Knoke, 2002, p. 290). Some researchers put emphasis on size, density, reciprocity, connectivity, multiplexity, cohesion, interlocks, goal-consensus, trust, legitimacy, formalization, transaction costs, information exchange, and social embeddedness (Zaheer et al., 1998; Kenis \& Knoke, 2002).

It seems that the research on inter-organizational relations supports social psychological theory about socialization understood as whe process of interaction through which an individual (a novice) acquires the norms, values, beliefs, attitudes, and language characteristic of his or her group « (Gecas, 2001, p. 2855). From network theory, we can deduce that such beliefs, values, norms and attitudes can be maintained by the formal and 
informal features of the governance structures. This will be described in the next section.

The characteristics of the context of a network have diverse implications. Some studies find that various types of inter-organizational ties have different effects on performance and this, in turn, is contingent on the favorability of the markets (op cit Gulati \& Higgins, 2000, p. 137). Discontinuities can cause problems of understanding, different interpretations of the same phenomena, ambiguity and framing. Especially in the early phases of network development, unfamiliarity among the members can cause serious problems. This is even more the case because a network develops an enacted context for each of the participants, and the context of this network is an additional layer restricting or enabling participants to act. The difficulties and adversities in the context of the network, which is itself a self-initiated context, mean that huge investments in mutual relations are necessary. Some researchers have examined "which conditions facilitate and constrain the formation of ... networking relation« (Provan \& Kenis, 2007). An in-depth study, conducted by Doz (1996), presents a model in which he shows show specific initial conditions (task definition, partners' routines, structure of the organizational interface, and actors' expectations) facilitate or hamper partner learning (about the environment, tasks, process, skills, goals) « (Ebers, 2002, p. 8). If the environmental context does not value collaboration, it is difficult to establish inter-organizational relationships, and instead of cooperation, competition might be the result.

As to the importance of the developmental phase of the network, Larsson (1992) identified three phases in networking relations: (1) a pre-working stage in which the preconditions for network are decided, (2) establishment of network relations, and (3) the commitment phase, in which the networking relations are solidified. Gray (Gray, 1987) writes about: (1) a problem-setting phase, in which potential partners identify their common interest, (2) a direction-setting phase, in which potential networking partners present their values to »develop a sense of common purpose«, and finally (3) a structuring phase, in which the partners build and develop stricter institutions by regulating mutual support towards their operative actions. Thus, the mentioned scholars identify the characteristic set of contingencies that facilitate and constrain each phase and provide us with $»$ a more detailed account of the conditions of network formations" (Ebers, 2002, p. 7). Other studies of longitudinal character "provide 
evidence that once network relations are established, experience with networking, mutual learning, and diversity of ties stimulate the formation of further networking relationships« (Ebers, 2002, p. 8).

As to the governance structure, network theory does not ignore the importance of how networks are managed. Classic theory suggests that hierarchy and steering are optimal, and they may be the only ways to manage a network. Network analysts measure this by the centrality of actors in a network, the existence of cliques and clusters. Kenis and Provan argue (Provan \& Kenis, 2007, p. $9 \mathrm{ff}$.) that whe successful adaptation of a particular form of governance« is due to the key structural and relational contingencies as e.g., trust, size, goal consensus and the nature of tasks. They identify different basic relationships spanning the mentioned contingency factors and according to them: The greater the inconsistency between critical contingency factors and a particular governance form (both in terms of the number of inconsistent factors and the extent to which these factors are inconsistent with characteristics of the form of governance), the less likely that particular form will be effective. This, in turn, will lead either to overall network ineffectiveness, dissolution, or changing the form of governance. This is the case because there is a dilemma involving trust and governance in which too much governance/steering can be costly, but too little can be just as costly because of inadequate formal safeguards in reducing opportunistic behavior. Those responsible often opt for steering in an effort to minimize the second failure without realizing the costs involved with such steering.

As to the structural features of networks, Krackhardt (1994) argued that by increasing network connectedness and achieving unity at higher levels of network density, hierarchy can be replaced. Hence, if the density and connectivity of a network increases, this in itself, could establish shared direction and purpose to the network as a whole. Trust can also substitute for formal governance (Lincoln \& Gerlach, 2004). The density of a network (number of actual ties given the potential number of ties in a network) as well as trust would serve as condition for information exchange, know-how, best-practices, innovativeness and technological performance (Tang \& $X_{i}, 2006$; Meagher \& Rogers, 2004). Furthermore, relational features can increase trust, especially when the ties are multiplex i.e., structurally diverse (Hannan \& Freeman, 1989) and simultaneously involve different aspects such as social bonds, business relations, normative expectations and roles, and affective aspects (Granovetter, 
1985). When only narrow channels between organizations exist, this might result in limited information exchange (Kenis \& Knoke, 2002) and e.g., trust decreases transaction costs (Gulati \& Nickerson, 2008). Foster Fishman et al., (Foster Fishman, 2001, p. 903) suggest that establishing multi-level alliances in multiple contexts and at multiple levels may be a promising venue for facilitating inter-organizational exchanges but even under optimal circumstances, agents can react very differently to the emerging network (Vincent, 2008). Alliances still can have difficulty recruiting critical stakeholders, maintaining active member involvement, promoting a collaborative work culture, and achieving collaborative outcomes (Foster Fishman et al., 2001, p. 901).

\subsection{Lessons from network theory}

Network theory posits that in order to build an organization/network in which values and norms are internalized by its employees, the following are necessary:

1. Creating and developing networks of actors is an advantageous alternative to both hierarchical steering and market-like individual self-steering. Networks can do without hierarchy by increasing the connectedness within the network and achieving unity at higher levels of network density

2. Investing in network relations should be a primary activity. This investment includes considering task definition, partners' routines, the structure of the organizational interface, and actors' expectations. This investment is especially important in adverse contexts.

3. Recognizing the self-reinforcing effect of investments in network relations. Once network relations are established, experience with networking, mutual learning, and diversity of ties stimulate the formation of further networking relationships.

4. Optimizing the structural features within networks such as density, connectivity and multiplexity.

\section{Conclusions and reflections}

This article argued that present-day procedures on public accountability miss the essence of being accountable. We address the point that the periodic, formal, routine-based accountability procedures that 
demonstrate that one's actions are permissible according to laws and regulations, come at the expense of being and feeling responsible for one's actions. We suggested that responsible accountability implies affective public service motivation, instead of rational and norm-based motivation. This requires actors to know how to deal with, handle and manage emotions; it can be propagated by proper socialization when individuals enter the organization; and it can be maintained by dense, multiplex interpersonal relations that involve more than just rational technical goal-oriented interactions.

This argument differs from those normally found in the literature because it provides an alternative to using the role of leadership and procedural coordination as driving forces.

The arguments found in social psychology and network theory point to the decisive role of peers or experienced organization members. In this view, it is not the role of leadership but the role of middle management that is crucial.

From social psychology, we can deduce that it is mainly middle management that guides new professionals through the socialization process. The values, norms, attitudes, and the perception of professionalism that these middle managers transfer to newcomers is crucially important. Social psychological theory tells us that this socialization of newcomers should take place when they first enter the organization. During these months, and perhaps even the first, year, middle managers can shape the newcomers' attitudes. Therefore, clear guidance that transfers the right values and professional attitude is indispensable.

According to network theory, these values can be maintained by governance structures that build trust among actors, by individuals or organizations, and by dense networks, interlocking relations, informationexchange, connectivity and especially multiplexity.

This method is called soft steering, not because we assume that group pressure is less persuasive than hierarchical orders, but because it is intended to propagate the affective dimension of such motivation as opposed to the rational or norm based dimensions of public service motivation. As such, it poses an alternative to hierarchy, punishment and rewards by economic incentives, and norm-based behavior by extensive laws and regulations. 
We could have posed another question, namely, whether public accountability should be abandoned entirely based on the criticism it faces, i.e. it is costly, useless, ineffective, biased, immoral. We think that would be premature. The classic goals of accountability justify its prominence in public administration, and the criticisms are not directed at accountability as such, but at the types of implementation of accountability that bring the negative side-effects to the fore.

Whether soft steering is effective remains to be seen, and much more empirical research is required. While socialization theories and network theories have both received substantial criticism, they are useful for our purposes since they provide an appealing answer to our research question of how to make public accountability work in such a way that it enhances responsibility among the stakeholders. These theories imply that public accountability works best when people do what they are expected to do because they are committed to their work, they care about the welfare of the client, and they are committed to the importance of the program, coaching, guiding and comforting clients.

Dr. Michiel S. de Vries is full professor and chair in Public Administration at the Radboud University of Nijmegen, honorary professor at the University of Aruba and visiting professor at Masaryk University of Brno. He is vicepresident of IASIA, the chair of the IASIA working group on Local Governance and Development and the chair of the NISPACEE working group on Public Administration Reform in Central and Eastern Europe and Central Asia. His latest books are Improving Local Government (Palgrave), The Importance of Neglect in Policy Making (Palgrave), The Story behind Western Advice to Central Europe during its Transition (NISPAcee Press) and Value and Virtue in Public Administration (Palgrave, 2017 ).

Dr. Iwona Sobis is Associate Professor in Public Administration at Gothenburg University. Her doctoral dissertation (2002) was about Public Administrative Reforms during the transition from socialism to market economy in Poland with a special focus on adaptation of a socialist employment service to a market economy. The general conclusion was that the European Union assistance proved a very influential force behind the adaptive strategies. Her later research also addressed the Western technical aid-chain to the Central and Eastern Europe countries in transition which resulted in the book: The Story behind Western Advice to Central Europe during its Transition (NISPAcee Press, 2009). 


\section{References}

- Argyris, C. (1960). Understanding Organisational Behaviour. Homewood, Illinois: The Dorsey Press Inc.

- Arrow, K. J. (1985). The Economics of Agency. In J. W. Pratt and R. J. Zeckhauser (eds). Principals and Agents: The Structure of Business (37-51). Boston, MA: Harvard Business School Press.

- Armstrong, M. (2006). A Handbook on Human Resource Management. London: Kogan \& Page.

- Ayeni, V. (2004). Public sector reforms in developing countries: A Handbook of commonwealth experience. London: Commonwealth Secretariat Publisher.

- Bačlija, I. (2011). Local Management and New Public Management. Uprava/Administration IX(4), 117-153.

- Barringer, B. R. \& Harrison J. S. (2000). Walking a Tightrope: Creating Value Through Interorganizational Relationships. Journal of Management (26), 367-403.

- Bem, D. J. (1972). Self Perception Theory. In: J. L. Berkowitz (Ed.). Advances in Experimental Social Psychology (6), 1-62.

- Brewer, G. A., Coleman, S. \& Facer II, R. L. (2000). Individual Conceptions of Public Service Motivation. Public Administration Review (60) 254-264.

- Cropper, S., M. Embers, M., Huxham, C., Smith Ring, P. (Eds.). (2008). The Oxford handbook of inter-organizational relations. Oxford: Oxford Handbooks.

- De Vries, M. S. (2007). Accountability in the Netherlands: Exemplary in its complexity. Public Administration Quarterly (31), 480-507.

- De Vries, M. S. (2010). War inside public administration: Interpersonal conflicts in Dutch municipalities and provinces. Annual Conference of the International Association of Schools and Institutes of Administration, IIAS/IASIA. Bali Indonesia, July 2010.

- Downs, A. (1967). Inside Bureaucracy. Boston, MA: Little.

- Doz, Y L. (1996). The Evolution of Cooperation in Strategic Alliances: Initial Conditions or Leaming Processes? Strategic Management Journal (17), 55-83.

- Ebers, M. (1997, 2002). Explaining Inter-Organizational Network Formation. (10.1.1.111.5848[1].pdf)

- Evan, W. (1966). The organization set: toward a theory of interorganizational relations. In James D. Thompson (Ed.). Approaches to Organizational Design (173-191). Pittsburgh.

- Festinger, L., \& Carlsmith, J. M. (1959). Cognitive consequences of forced compliance. Journal of Abnormal and Social Psychology (58), 203-210.

- Foster Fishmann, P. G., Salem, D. A., Allen, N. A. \& Fahrbach, K. (2001). Facilitating inter-organizational collaboration. American Journal of Community Psychology (29), 875-905. 
- Frederickson, H. G. \& Hart, D. K. (1985). The Public Service and the Patriotism of Benevolence. Public Administration Review (45), 547-553.

- Frost, P. J., Dutton, J.F., Maitliss, S. et al. (2005). Seeing Organizations Differently: Three lenses on Compassion. In: Door Stewart Clegg et al. (Eds.). The Sage handbook of organization studies (843-867). Thousand Oaks, CA: Sage.

- Galaskiewicz, J. (1985). Inter-organizational relations. Annual Review of Sociology (11), 281-304.

- Gecas, V. (2001). Socialization. In: Borgatta, E. F. \& Montgomery R. J. V. (Eds). Encyclopedia of Sociology. Vol. 4. (2nd ed.). New York: Macmillan Reference USA (5). 2855-2864.

- Goldsen, R. K. (1960). What College Students Think. Princeton, N. J.: Van Nostrand.

- Goslin, D. A. (ed.). (1999). Handbook of Socialization Theory and Research. Chicago: Rand McNally. Greenhouse.

- Grandori, A. \& Soda, G. (1995). Inter-firm Networks, Antecedents, Mechanisms and Forms. Organization Studies (16), 183-214.

- Granovetter M. (1985). Economic action and social structure: the problem of embeddedness. American Journal of Sociology (91), 481-510.

- Gray, B. (1987). Conditions Facilitating Interorganizational Collaboration. Human Relations. (38) 911-36.

- Gulati, R. \& Higgins, M.C. (2003). Which Ties Matter When? The Contingent Effects of Interorganizational Partnerships on IPO Success. Strategic Management Journal. (24) 127-144.

- Guy, M. E., Newman, M. \& Mastracci, S. H. (2008). Emotional Labor: Putting the Service in Public Service. New York: M. E. Sharpe.

- Heider, F. (1946, 1958). The Psychology of Interpersonal Relations. New York: John Wiley and Sons.

- Homans, G. (1961). Social Behavior. New York: Harcourt.

- Jennings, M. K. \& Niemi, R. G. (1968). The Transmission of Political Values from Parent to Child, The American Political Science Review (62), 169-184.

- Kahn, W.A. (1998). Relational systems at work. Research in Organizational Behavior (20), 39-76.

- Kaplan, H. B. (2001). Social Psychology. In: Borgatta, E. F. \& Montgomery, R. J. V. (Eds.). Encyclopedia of Sociology. Vol. 4. (2nd ed.). New York: Macmillan Reference USA. (5). 2766-2780.

- Kenis, P. \& Knoke, D. (2002). How organizations field networks shape interorganizational tie-formation rates. Academy of Management Review (27), 275-293.

- Knoke, D. \& Wright-Isak, C. (1982). Individual Motives and Organizational Incentive Systems. Research in the Sociology of Organizations (1), 209-254. 
- Krackhardt, D. (1994). Graph theoretical dimensions of informal organizations. In: Carley, K. M. \& Prietula, M.J. (Eds.) Computational organization theory (89-111). Hillsdale New York: Lawrence Erlbaum Ass.

- Larson, A. (1992). Network Dyads in Entrepreneurial Settings: A Study of the Govemance of Exchange Relationships. Administrative Science Quarterly (37), 76-104.

- Lincoln, J. R. \& Gerlach, M. L. (2004). Japan's Network Economy: Structure, Persistence, and Change. Cambridge: Cambridge UP.

- Marini, M. M. (2001). Social values and norms. In: Borgatta, E. F. \& Montgomery, R. J. V. (Eds.). Encyclopedia of Sociology. Vol. 4. (2nd ed.). New York: Macmillan Reference USA, (5). 2828-2840.

- Mead, G. H. \& Strauss, A. (1934, 1956). On Social Psychology. Selected Papers. Chicago and London: Phoenix Book, The University of Chicago Press.

- Meagher, K. \& Rogers, M. (2004). Network density and R\&D Spillers. Journal of Economic Behaviour and Organization (53), 237-260.

- Oliver, C. (1990). Determinants of Inter-organizational relationships: Integration and Future Directions. The Academy of Management Review (15), $241-265$.

- Olson, O., Humphrey, C. \& Guthrie, J. (2001). Caught in an evaluatory Trap: A dilemma for public services under NPFM. The European Accounting Review (10), 505-522.

- Osgood, C. E., Suci, G. J. \& Tannenbaum,P. H. (1957). The measurement of meaning. Urbana, USA: University of Illinois Press.

- Perry, J. L. (1996). Measuring Public Service Motivation: An Assessment of Construct Reliability and Validity. Journal of Public Administration Research and Theory (6), 5-22.

- Perry, J. L., \& Recascino Wise, L. (1990). The Motivational Bases of Public Service. Public Administration Review (50), 367-73.

- Pfeffer, J. (1982). Organizations and Organization Theory. Boston: Pitman.

- Pfeffer, J. \& Salancik, G. R. (2003). The External Control of Organizations. A Resource Dependency Perspective. Stanford: Stanford Business Classics.

- Pollitt, C. \& Bouckaert, G. (2004) Public Management Reform. A Comparative Analysis. Oxford: Oxford University Press

- Provan, K. G., Fish, A. \& Sydow, J. (2007). Interorganizational Networks at the Network Level: A Review of the Empirical Literature on Whole Networks. [Online]. Available from: http://www.usc.edu/schools/sppd/bedrosian/private/docs/Network_review_ar ticle.pdf [28 December 2009].

- Provan, K. G. \& Kenis, P. (2007). Modes of Network Governance: structure, management and effectiveness. Journal of Public Administration Research and Theory (18), 229-257.

- Rokeach, M. (1973). The Nature of Human Values. New York: John Wiley. 
- Rousseau, D. (1994). Two Ways to Change and Keep the Psychological Contract: Theory Meets Practice. Executive Summary for the International Consortium for Executive Development Research. Lausanne.

- Rousseau, D. M. (1995). Promises in action: Psychological contracts in organizations. Newbury Park, CA: Sage.

- Schein, E. H. (1965, Reprinted 1980). Organizational psychology. New Jersey: Englewood Cliffs.

- Sobis, I., de Vries, M.S. \& van den Berg, F. (2012). The limits of leadership. The Nispacee journal of Public administration and Policy. Forthcoming.

- Tang, F. \& Xi, Y. (2006). Exploring dynamic multi-level linkages in interorganizational networks. Asia Pacific journal of Management (23), 187-208.

- Tannenbaum, S. I., Beard, R. L., \& Salas. E. (1992). Team building and its influence on team effectiveness: An examination of conceptual and empirical evidence. In: Kelley, K. (Ed.). Issues, Theory, and Research in Industrial/Organizational Psychology. Amsterdam: Elsevier Science Publishers.

- Tomaževič, N. (2010). Social Responsibility and Governance - Management Process as a Basis of Excellence in Public Administration. Uprava VIII(4), 59-81.

- Van Maanen, J. \& Schein, E. H. (1979). Toward a theory of organizational socialization. Research in Organizational Behavior (1), 203-264.

- Van de Ven, A. H. (1976). On the nature, formation and maintenance of relations among organizations. Academy of Management Review (1), 24-36.

- Weick, K. E. (1995). Sensemaking in Organizations. Thousand Oaks: Sage Publications.

- Wellin, M. (2007). Managing the Psychological Contract. Using the Personal Deal to Increase Business Performance. Farnham: Gower, publ.

- Zaheer, A., McEvily, B. \& Perrone, V. (1998). Does trust matter? Exploring the effects of interorganizational and interpersonal trust on performance.

Organization Science (9), 141-159. 
POVZETEK

\section{JAVNA ODGOVORNOST S POMOČJO MEHKEGA KRMILJENJA}

Ključne besede: odgovornost, socializacija, teorija mrež, zmanjšanje administrativnih stroškov, socialna psihologija

Ta članek predstavlja stališče, da današnji postopki v zvezi z javno odgovornostjo niso v skladni s samim bistvom odgovornosti, in predlaga alternative, ki jih ponujata teorija socialne psihologije in teorija mrež.

Članek na začetku ugotavlja, da redni, formalni, rutinski postopki uveljavljanja odgovornosti, ki sporočajo, da so posameznikova dejanja dopustna glede na zakone in predpise, slabijo občutek odgovornosti za lastna dejanja. Takšno odgovornost, ki temelji na nadzoru in hierarhiji, pogosto spremljajo ogromni stroški upravljanja, hkrati pa ima majhno praktično uporabnost, saj je takšen sistem odgovornosti pogosto pristranski, nima zadostnih kazalcev odgovornosti, če gre kaj narobe, in slabi tako imenovano motivacijo javnega sektorja.

Alternativa je zavzeta odgovornost, kar pomeni čustveno motivacijo javnega sektorja namesto racionalne motivacije na podlagi norm. Ta od akterjev zahteva, da se znajo soočati s čustvi, jih obravnavati in obvladovati; lahko se širi s primerno socializacijo ob posameznikovem vstopu $v$ organizacijo in vzdržuje prek tesno povezanih, mnogoplastnih medosebnih odnosov, ki obsegajo več kot le racionalno, tehnično in ciljno usmerjeno sodelovanje.

Odgovor na vprašanje, kako to doseči, ponujata teoriji socialne psihologije in mrež.

Teorija socialne psihologija izpostavlja, da zgolj finančno nagrajevanje za vedenje, ki ga zaposleni dejansko izvaja, samo povečuje kognitivno neusklajenost in s tem brezbrižnost oziroma stres. Ta teorija tudi pravi, da ima socializacija - posebno s strani izkušenih članov organizacije/sodelavcev - lahko določene prednosti. Posledice takšne socializacije so jasnost in skladnost vzajemnih pričakovanj delodajalca in delavca ter celo pojav, ki se $\vee$ socialni psihologiji imenuje psihološka pogodba, ti. jasno zavedanje delavca, kakšna dejanja se pričakujejo od njega in kakšen odziv lahko v zameno pričakuje od delodajalca. 
Argyris (1960) je prvi uporabil termin psihološka pogodba in ga opredelil kot nenapisan dogovor med skupino zaposlenih in njihovim nadrejenim. "Psihološko delovno pogodbo" je orisal prav na način, ki ga iščemo, in sicer »bo delavec ohranjal visoko storilnost» ter zmanjšal nadzor in kontrolo, medtem ko »delovodja jamči in spoštuje norme neformalne kulture zaposlenih", tako da mu omogoča opraviti določeno nalogo, mu zagotavlja primerno plačilo in varno zaposlitev. Socialna psihologija prav tako trdi, da mora do te socializacije novincev priti ob vstopu $v$ organizacijo. $V$ prvih nekaj mesecih, morda celo $v$ prvem letu, lahko srednji vodstveni delavci oblikujejo odnos novincev. Jasno usmerjanje, ki posreduje prave vrednote in strokoven odnos, je nujno potrebno.

Prav tako je treba novince izpostavljati situacijam, $v$ katerih bo zagotovo prišlo do kognitivnega neravnovesja, nezdružljivosti ali neusklajenosti, in jih izuriti, da prilagodijo, okrepijo ali pretehtajo svoje zaznavanje v skladu strokovnimi vrednotami in ob tem razumeti, da je odločilna vloga srednjega vodstva veliko boli ključna kot vloga vodstva. Srednii vodstveni delavci morajo nove delavce/nove strokovnjake usmerjati in na novince prenesti odnos in vrednote, ki so za organizacijo velikega pomena, ter si prizadevati za nenapisan vzajemen dogovor o pričakovanjih - psihološko pogodbo - ki ni samo transakcijska pogodba o plačilu za delo ali individualizirana pogodba o zaposlitvi, temveč rezultat obsežnega procesa socializacije, ki vključuje proces učenja in prilagajanja zaznavanja, kar ustvarja vzajemno in očitno upravičeno zaupanje, nadzor pa se lahko temu ustrezno zmanjša. Literatura o socialni psihologiii prav tako kaže, da je zdržnost pridobljenega znanja, veščin in usvojenih vrednot odvisna od taktike, ki je bila uporabliena med socializacijo.

Odgovor na vprašanje, kako zagotoviti zdržnost vrednot, priučenih s socializacijo, ponuja teorija mrež. Po teoriji mrež te vrednote lahko ohranjamo s strukturami upravljanja, ki gradijo zaupanje med akterii s pomočjo posameznikov ali organizacij ter s pomočjo gostih mrež, prepletenih medsebojnih odnosov, izmenjave informacij, povezanosti in še posebej večplastnosti. Teorija mrež uči, da je oblikovanje in razvijanje mrež akterjev ugodnejša rešitev kot hierarhično krmiljenje in tržnemu podobno individualno samokrmiljenje. Mreže se lahko odpovejo hierarhii, tako da krepijo povezanost znotraj mreže in dosegajo enotnost z višjo stopnjo gostote mreže. Zato bi moralo biti vlaganje $v$ mrežne odnose prvenstvena dejavnost. Takšno vlaganje zajema razmislek o definiciji nalog, postopkih partnerjev, strukturi presečišča organizacije in 
pričakovanjih akterjev. To vlaganje je posebno pomembno $v$ neugodnih okoliščinah.

Ta metoda se imenuje mehko krmiljenje, pa ne zato, ker bi domnevali, da je skupinski pritisk mani prepričljiv kot hierarhične ureditve, temveč zato, ker je namenjeno širjenju čustvene razsežnosti tovrstne motivacije $v$ nasprotju z racionalni razsežnostmi motivacije javnega sektorja na podlagi norm. Kot takšna predstavlja alternativo hierarhiij, kaznovanju in nagrajevanju z ekonomskimi spodbudami ter na normah temelječem vedenju zaradi obširnih zakonov in predpisov.

Ali je mehko krmilienje učinkovito, se bo še pokazalo in treba bo opraviti še veliko več empiričnih raziskav. Teorije o socializaciji in mrežah ponujajo privlačen odgovor na naše raziskovalno vprašanje, kako poskrbeti, da bo javna odgovornost delovala na način, ki krepi odgovornost med deležniki. Iz teh teorii izhaja, da javna odgovornost najbolje deluje, kadar liudje delajo, kar se od njih pričakuje, zato, ker so predani svojemu delu, jim ni vseeno za dobrobit stranke in so predani pomenu programa ter stranke poučujejo, usmerjajo in $z$ njimi sočustvujejo. 